\title{
Principals' Assimilation Techniques and Work Behaviour of Newly Employed Teachers in Private Secondary Schools in Rivers State, Nigeria
}

\author{
Dr. Ukaigwe, P. C*, Uchenyi, T. I \\ Department of Educational Management Faculty of Education, University of Port Harcourt, Rivers State, \\ Nigeria \\ *Corresponding Author: Dr. Ukaigwe, P. C, Department of Educational Management Faculty of \\ Education, University of Port Harcourt, Rivers State, Nigeria
}

\begin{abstract}
This study investigated principals' assimilation techniques and work behaviour of newly employed teachers in private secondary schools in Rivers State, Nigeria. Two research questions guided the study, while two hypotheses were tested. The study adopted correlation design. The population of the study comprised 389 principals and 463 newly employed teachers serving in the private secondary schools in Rivers State. A sample of the study was 172 elements comprising 86 principals and 86 newly employed teachers in private secondary schools in Rivers State. The first and second instruments used were self-designed questionnaires titled 'Principals' Assimilation Techniques Questionnaire' (PATQ) and 'Teachers' Work Behaviours Assessment Questionnaire' (TWBAQ). The instruments were validated and subjected to reliability tests, in which indexes of 0.82 and 0.84 were obtained using test-retest and Pearson Product Moment Correlation (PPMC) techniques. The data generated were analysed using Regression Statistics to answer research questions and to test the hypotheses at 0.05 alpha level. The findings of the study revealed that positive and strong relationship existed between induction and work behaviour of newly employed teachers in private schools in Rivers State. The study further revealed that positive and weak relationship existed between supervision and work behaviour of newly employed teachers in private secondary schools in Rivers State. Recommendations made included that School managers should re-evaluate the modalities used in supervising newly employed teachers with a view to improving its processes to foster assimilation of newly employed teachers. The study also recommended that school leadership should ensure that adequate supports are given to newly employed teachers during their probation period. In addition, administrators should assess the strengths and weaknesses of newly employed teachers in order to determine the areas they need supervisory supports to improve on their performance abilities in classroom.
\end{abstract}

Keywords: Principals, Assimilation, Techniques, Work Behaviour, Newly-Employed, Teachers, Private Secondary Schools, Rivers State, Nigeria.

\section{INTRODUCTION}

Teaching today is increasingly becoming a complex occupation, requiring the highest standards of professional practice to perform it. It is a core profession that has so much influence on the effectiveness of other professions. As a key agent of change in today's knowledge-driven society, teachers serve as midwives in the propagation of knowledge society. Without their competence, the future of the school system will be in danger, so also the quality of education (Ukaigwe \& Igbozuruike, 2019). This highlights the importance of teachers in the promotion of effective and functional education. Teachers have powerful and long-lasting influences on their students. This is because they directly affect how students learn, what they learn, how much they learn, and the ways they interact with one another and the world around them.

Inconsideration of the degree of the teacher's influence on the students, teachers must understand and seek for better ways of performing their duties; they need to be assisted to raise their positive work behaviours so that students' academic achievement will improve. This is particularly important for a newly employed teacher, who has insufficient teaching skills and practical experiences to excel as a teacher. Thus, in order to help newly-employed teachers to exhibit positive work behaviours that aid work performance, the school system and the administrators particularly must put in place adequate 
assimilation processes that reinforce positive work behaviours that is not only enhance effective teaching and learning, but also helps to improve students' academic achievement and desirable outcomes. Assimilation processes can be seen as a series of programmes and professional development activities that are organized and programmed to acclimatize the newly employed teachers into the school system.

The relevance of teachers' assimilation is well recognized in literature. This is because it enables the newly employed teachers to become acquainted with the school routines and other norms that will not only help beginner teachers to become more knowledgeable on pedagogical skills application, but will also enable them to develop professional identity in the school and advance professionally in their teaching careers. Thus, assimilation programmes such as induction and supervision are considered as key tools for dispelling the fears and anxieties that often cause newly employed teachers to experience reality shocks when they enter new environment or classroom (Nghaamwa, 2017).

There are considerable numbers of private secondary schools in Rivers State, offering secondary education services to residents of the state. A preliminary observation suggested that some private secondary school in Rivers State rarely adhered to regulations concerning teachers' management practices, with the result that some even employ persons that have no teaching qualification as a teacher. Apart from these categories of teachers that have invaded teaching profession, the newly employed teachers that are duly qualified surely need orientation and supervisory supports to enable them to assimilate properly into the school system in order to carry out their duties more effectively (Lunenburg, 2011). The cardinal aim of assimilation is to acclimatize the novice teachers into teaching profession, which is not only considered as key to fostering high productivity on the part of beginner teachers, but also necessary for helping them to fully adapt to the school environment and remaining in teaching profession (Mingo, 2012). This is because many teachers that entered teaching profession who were presumably not properly assimilated into the teaching profession left within one to three years of employment (Grimble, 2017). In addition to the above, the principal function of the school is to educate and groom individuals into useful member of the society. Ensuring that teachers are professionally competent and fit for their job requires that new entrants into the teaching profession must be assimilated into the profession and given sufficient support to do so, including material and nonmaterial support necessary for strengthening their competencies and confidence in job performance. This is particularly essential because the first three years of career in teaching profession is a critical period for the new teachers - a period during which newly employed teachers are considered as beginner teachers and require support to develop teaching philosophies and professional identities that will shape their choices of teaching methods (Cook, 2009), love for or discontent for teaching profession (Hangul, 2017) and decide to grow their career in or exit the profession.

Observations suggested that private schooling in Rivers State is not properly managed and supervised by the state Ministry of Education. This perhaps, was responsible for the discernable lack of inadequate attention given to teacher assimilation processes in private schools in the state. It is therefore of no wonder that Nwadiani (2008) remarked that teachers are poorly treated and poorly paid in Nigeria, with the result that their apparent rejection by the society and experiences at place of work seems to have combined with inadequate assimilation processes to cause considerable number of them to exit the profession within five years of employment. It is therefore of no surprise that Kukuru (2018) attributed teachers' turnover and negative work behaviours on the part of teachers, to lack of professional development programmes that ought to help newly employed teachers to become well assimilated into the school system where they are employed.

As good as these assimilation processes might be, it is unclear whether private secondary schools in the state are using the highlighted key assimilation processes to support newly employed teachers as strategies for making them feel valued by the school, which will in part help to them keep them in the teaching profession, improve their of life and quality of their services through better classroom management, enhanced teaching skills and so on.

\section{Statement of the Problem}

It is believed that newly-employed teachers in any school system need to be adequately assimilated into the school system in order to enhance their work behaviour. Such assimilation processes may be 
through induction and supervision programme. However, in many private secondary schools in Nigeria and Rivers State particularly, it appeared that the newly-employed teachers in these schools are not fully being assimilated into the system. This was considered to have emanated from the fact that some school administrators have not in place, a functional assimilation processes that reinforce positive work behaviours. In some cases the teachers do not adhere to school rules and regulations; instead they involve themselves in unruly behaviours such as absenting themselves from school and in some cases, came to school at will and late.

Consequently, it looked as if there were an absence of induction programme designed to assist the new-employed teachers to update themselves in terms of knowledge and skills, as well as charging them for effective teaching. This was compounded by perceived absence of adequate supervision as a means of providing the teachers with the opportunities for developing professional and reflective understanding, via supervisory supports from their experienced colleagues. The consequence of these was that work behaviours of some of the newly employed teachers seemed very discouraging in the sense that there were no new innovations in their service delivery.

However, in the schools where these assimilations processes were observed, the extent of their successes in enhancing positive work behaviours among teachers was uncertain and unclear at best. Thus, this study sought to ascertain the degree to which teacher induction and supervision improved the work behaviours of beginner teachers in private secondary school in the Rivers State.

\subsection{Aim and Objectives of the Study}

The aim of this study was to investigate the relationship between principals' assimilation techniques and work behaviours of newly-employed teachers in private secondary schools in Rivers State. The specific objectives of the study were to:

- Examine the relationship between induction and work behaviour of newly-employed teachers in private secondary schools in Rivers State.

- Find out the relationship between supervision and work behaviour of newly-employed teachers in private secondary schools in Rivers State.

\subsection{Research Questions}

The following research questions were answered in the study:

- What is the relationship between induction and work behaviour of newly-employed teachers in private secondary schools in Rivers State?

- What is the relationship between supervision and work behaviour of newly-employed teachers in private secondary schools in Rivers State?

\subsection{Hypotheses}

The following hypotheses were tested in the study at 0.05 significant level.

- There is no significant relationship between induction and work behaviour of newly-employed teachers in private secondary schools in Rivers State.

- There is no significant relationship between supervision and work behaviour of newly-employed teachers in private secondary schools in Rivers State.

\section{CONCEPTUAL FrameWORK}

\subsection{The Concept of Induction}

The term 'induction' has considerable degree of divergent definitions and application variations in both educational and institutional contexts. Lopez (2015) defined induction as goal directed educational programme that focuses on addressing the learning needs of newly employed teachers, by way of teaching them the principles and ethics that govern teaching profession. Similarly, Kessels (2010) defined induction programme as a process of introducing beginner teachers into their new post and familiarizing their roles with official responsibilities as teachers, alongside with associated obligations as members of the school community. Furthermore, induction has also been defined as the 
process by which newly employed teachers are incorporated and symphonized into school community, so that they will become effective members of the school community (Nghaamwa, 2017).The cardinal objective of induction is to provide enough support for newly employed teachers to navigate through the challenges that beset beginner teachers, and also to help them to move forward in their career as a teacher (Hendrik, 2016). Although induction programme may take place during probation period or before the new teacher is assigned duties (Ikegusi \& Modebelu, 2016), its ultimate goal is to impart, integrate the beginner teacher into the school community (Belanger, 2018), and to school them on the behaviour that support effective teaching and learning (Grimble, 2017).

Wrong (2004) highlighted that the pivotal role of school and teacher is not only centred on helping students achieve academically, but teaching students how to succeed in life. The scholar emphasised that the school can only achieve this goal if the most contributing factor in educational process (the teacher) is properly educated on the pedagogical skills and enabling behavioural facilities that aid teaching and learning. Nakpodia (2008) remarked that the effectiveness of induction exercise predict the degree of challenges a novice teacher is likely to encounter during probation, as well as the likelihood of remaining in teaching profession(as cited by Nghaamwa, 2017). This is because if the induction programme fails to allay the fears and doubts about succeeding as a teacher, provide succour to the new teacher and sense of belonging, the novice teacher will with time become disconnected with the school community, which will pave way for dissatisfaction and eventual withdrawal from the school.

Mlindazwe (2010) acknowledged that teachers normally face varying degrees of fears during their first few years of employment in the profession, noting that induction programmes must be designed to address those jitters. This view is in line with the observations of Kearney (2011) who stated that the challenge of adjusting to the new work behaviours expected of newly employed teachers could be confusing. The scholar further noted that induction programme is designed to provide assistance to the novice teachers, as a tool for helping them to blend smoothly into their new roles alongside with the behavioural expectations associated thereto.

As the new teacher travails in attempt to balance apply learnt contradictory theories in a pragmatic and unfamiliar environment classroom setting, she is faced with strain and burnout may ensue and even deteriorate into discontentment and attrition. Attrition in this context is the number of newly employed teachers that exit teaching profession before the sixth year of their employment (Mingo, 2012). Owens (2015) reported that $44 \%$ of newly employed teachers do not stay beyond five years in teaching profession due to inadequacies of administrative support, poor working environment and lack of quality instructional resources as well as the resultant burnout arising from the above factors. The findings of Owens is supported by observations of Nghaamwa (2017) who opined that unfavourable working environment causes novice teachers to undergo unnecessary stress that not only affects their confidence and self-worth, but also their professional identity and growth. Thus, it is imperative that newly employed teachers are not exposed to impressions that will cast scepticism about their career choices in education. In this regard Lunenburg (2011) urges that strong and institutionalize support programmes like induction, should be provided for the newly employed teachers; a platform whereby they are educated on how to do their jobs better, by actual guidance on how to swim rather than left to sink. This is because learning by trial and error without guidance of more knowledgeable teachers is not only wasteful and morale dampening, but also costly to the school that employed the new teacher.

Dishena (2014) observed that induction programme is directly and indirectly associated with improvement in academic achievement of students, because it reduces attrition rate and unprofessional conducts such as absenteeism, child abuse, and other indecent behaviours, and at the same time enhances understanding of school's policies, hierarchical relationships, pedagogical skills, and job satisfaction of the new teacher. This is in line with the views of European Commission (2010) who observed that effective induction exercise boost the teaching skills, knowledge of the school and commitment of the newly employed teachers, which is not only essential in helping them to become efficient worker, but also enhances their desire to grow progressively in teaching profession - an antidote to teacher attrition. 


\subsection{The Concept of Supervision}

The concept of supervision has many definitions based on different conceptions and contexts. Modebelu (2008) defined supervision as the process whereby an experienced teacher takes the responsibility of overseeing the work-related activities of a less experienced teacher with a view to providing assistance, guidance and direction, motivation and supports needed to improve the teaching skills of the beginner teacher.

There are two basic type of supervision namely internal and external supervision.

\subsubsection{External Supervision}

External supervision is the type of supervision in which the officials of State Ministry of Education and Post-primary Education Management Board visit both public and private schools to evaluate and determine the extent of their compliance to state policies and standards on schools operations. The functions of external supervisors are similar to that of inspectors- whose job is more of checking the extent schools programmes, teachers and instructional facilities conform to set standard (Abraham, 2013).

\subsubsection{Internal Supervision}

Internal supervision is the type of supervision carried out within the school environment by the school leadership. The internal supervision is mainly coordinated and done by the principal, head of department, and head teachers with considerable experience or designate of the principal. Abraham (2013) identified the tripartite principles of effective supervision as thus;

\subsection{The Principle of Democracy}

In this principle, the supervisor is expected to be democratic in the courses of performing supervisory her tasks. She is expected to accord the supervisee (new teachers) the required dignity and deserved respect. This principle applies both ways; the newly employed teachers are also expected to accord maximum respect to their supervisors, and by so doing established cordial relationship that permit freedom to express one's views, seek for answers for contending questions and receive reasonable responses therewith.

\subsection{The Principle of Cooperation}

This principle is rooted in modern ideas that purport that collaborative efforts produce more results than master-learner approach. Thus, this principle encourages supervisors and their subordinates to work together in finding ways to enhancing instructional delivery. The shared understanding that both parties are working towards achieving common goal will cause both the supervisees and supervisor to work together to produce solutions to instructional difficulties.

\subsection{The Principle of Flexibility}

This principle recognizes the import of resilience, adaptability and innovation in solving educational problems. This principle encourages initiative and new ways of doing things better. Thus, it gives room for both supervisors and subordinates to operate within the dynamics of freedom to interrogate learning contents, teaching methods and other work behaviours within the context of fine-tuning the status quo for more effective results.

\subsection{Instructional Supervision}

Instructional supervision is one of the major areas a supervision in educational institutions. Okobia (2015) observed that instructional supervision is a professional assistance given by a knowledgeable supervisor to a less knowledgeable supervisee in areas of instructional delivery, in order to help the less experienced teacher to attain certain degree of instructional expertise. It is concerned with helping the beginner teacher to master the art of teaching and learning. This is usually achievable through classroom visitation, observation, demonstration, conferencing and evaluation (Abraham, 2013; Kaegon, 2012).

Furthermore, the findings of a study carried out by Sule, Ameh and Egbai (2015) showed that instructional supervision practices in classrooms was strongly associated with better work behaviours 
on the part of newly employed teachers. These findings corroborate the findings of Okobia (2015); Eya and Leanard (2012) whose respective studies revealed that supervision is exceedingly capable of accelerating change in work behaviour of teacher in the direction that enhances desirable abilities that epitomize a professional teacher. The implications of these findings suggest that lack of purposeful supervision is a negative function of poor work behaviour on the part of novice teachers, which by extension may lead to poor academic performance of students.

\section{MeThodology}

The study adopted correlation design. The population of the study was 852 elements, comprising 389 principals and 463 newly employed teachers serving in the private secondary schools in Rivers State. A sample of the study was 172elements comprising 86 principals and 86 newly employed teachers in private secondary schools in Rivers State. The stratified simple random sampling technique was used along with purposive sampling method to select the target respondents. The researcher randomly selected 10 Local Governments Areas (LGA) out of 23 LGAs in Rivers State, from which 10 private secondary schools that participated in the study were drawn randomly. Two instruments were used for data collection. The first and second instruments were self-designed questionnaires titled "Principals' Assimilation Techniques Questionnaire' (PATQ) and 'Teachers' Work Behaviours Assessment Questionnaire' (TWBAQ). The first instrument was administered to newly employed teachers that participated as sample of the study. The second instrument was administered to principals of private schools that participated in the study. The instruments were validated and subjected to reliability tests, in which indexes of 0.82 and 0.84 were obtained using test-retest and Pearson Product Moment Correlation (PPMC) techniques. The instruments consisted of two sections; Section A was designed to elicit demographic data of the respondents, while section B included 20 questionnaire items structured to obtain responses from the respondents, using likert scale ratings of Strongly Agree (SD), Agree (A), Disagree (D) and Strongly Disagree (SD). The data generated were analysed using Regression Statistics was used to answer research questions and to test the hypotheses at 0.05 alpha level.

\section{Data PRESentation AND Results}

Research Question One: What is the relationship between induction and work behaviour of newlyemployed teachers in private secondary schools in Rivers State?

Null Hypothesis One: There is no significant relationship between induction and work behaviour of newly-employed teachers in private secondary schools in Rivers State.

Table1: Regression analysis of the relationship between induction and work behaviour of newly-employed teachers in private secondary schools in Rivers

\begin{tabular}{|c|c|c|c|c|c|c|c|c|c|}
\hline Variables & $\mathbf{N}$ & Mean & SD & Df & $\mathbf{R}$ & R Square & P-value & Alpha Level & Remark \\
\hline Induction & 86 & 28.41 & 6.46 & \multirow[t]{2}{*}{170} & \multirow[t]{2}{*}{0.684} & \multirow[t]{2}{*}{0.462} & \multirow[t]{2}{*}{0.000} & \multirow[t]{2}{*}{0.05} & \multirow{2}{*}{$\begin{array}{l}\text { Ho } \\
\text { Rejected }\end{array}$} \\
\hline $\begin{array}{l}\text { Teacher work } \\
\text { behaviour }\end{array}$ & 86 & 41.53 & 9.75 & & & & & & \\
\hline
\end{tabular}

The analysis in table 1 yielded a correlation coefficient of 0.684 , which is positive and strong, and thus indicated that induction had positive and strong relationship with teacher behaviour. Furthermore, the above table 1 shows that at 170 degree of freedom and 0.05 alpha level, the regression analysis yielded a correlation coefficient of 0.684 . Since the p-value of 0.000 is lower than 0.05 alpha level, it is evident that the positive relationship between the two variables is significant, hence the researcher was constrained to reject the above null hypothesis and concludes therefore, that there was significant relationship between induction and work behaviour of newly employed teachers. Furthermore, the $\mathrm{R}$ square value of 0.462 indicates that $46 \%$ variance in new teachers work behaviour was attributed to or explained by induction exercise.

Research Question Two: What is the relationship between supervision and work behaviour of newly-employed teachers in private secondary schools in Rivers State?

Null Hypothesis Two: There is no significant relationship between supervision and work behaviour of newly-employed teachers in private secondary schools in Rivers State. 
Principals' Assimilation Techniques and Work Behaviour of Newly Employed Teachers in Private Secondary Schools in Rivers State, Nigeria

Table2: Regression analysis of the relationship between supervision and work behaviour of newly-employed teachers in private secondary schools in Rivers

\begin{tabular}{|c|c|c|c|c|c|c|c|c|c|}
\hline Variables & $\mathbf{N}$ & Mean & SD & Df & $\mathbf{R}$ & R Square & P-value & Alpha Level & Remark \\
\hline Supervision & 86 & 26.44 & 6.84 & \multirow[t]{2}{*}{170} & \multirow[t]{2}{*}{0.160} & \multirow[t]{2}{*}{0.026} & \multirow[t]{2}{*}{0.141} & \multirow[t]{2}{*}{0.05} & \multirow{2}{*}{$\begin{array}{l}\text { Ho } \\
\text { Accepted }\end{array}$} \\
\hline $\begin{array}{l}\text { Teacher work } \\
\text { behaviour }\end{array}$ & 86 & 41.53 & 9.75 & & & & & & \\
\hline
\end{tabular}

The analysis in able 2revealed a positive correlation coefficient of 0.160 , and thus indicated that supervision had positive relationship with teacher work behaviour. The results further show that at 170 degree of freedom and 0.05 alpha level the regression analysis yielded a correlation coefficient of 0.160 . Since the p-value of 0.141 is higher than the coefficient alpha level of 0.05 , the relationship between supervision and newly teachers' work behaviour is not significant; hence the researcher failed to reject the above null hypothesis and therefore concludes that there was no significant relationship between supervision and work behaviour of newly employed teachers. Furthermore, the R square value 0.026 indicates that $2 \%$ variance in teacher work behaviour was attributed to or explained by supervision.

\section{DisCUSSION OF FINDINGS AND IMPLICATIONS}

\subsection{Induction and Work Behaviour of Newly Employed Teachers in Private Secondary Schools}

As already established in the previous paragraphs, the findings of this study revealed that induction had positive and strong relationship with work behaviour of newly employed teachers in private schools in Rivers State. This was because induction programmes provided opportunities to boost the confidence of newly employed teachers, improved their teaching and communication skills and also helped them (new teacher) to acquire strategies for interacting and relating effectively with parents, students and co-workers among other members of the school community. The impact of induction was so significant that teachers' work behaviours improved in areas of punctuality, relational skills, cooperative skills, classroom management skills, teaching skills and communication skills, obedience to school regulations and familiarity with work performance procedures. These work behaviours are indicators of teacher productivity, thus the certitude of their contributions to students achievement is considerably undeniable. This means that induction exercise is an increasing function of teacher work behaviour, and thus implies that the more a given school organises effective induction the better the work behaviour of newly employed teachers and vice versa.

These findings suggest that familiarizing newly employed teachers with the culture and routine work procedures of the school helps to acquaint them with the school routine in a manner that helps them to fit-in and carry out their duties effectively. This finding is in line with Nagel (2014) and Timperly (2011) whose studies separately associated induction with better work behaviour on the part of newly employed teachers, adding that induction exercise helped to bring the behaviour of newly employed teachers into harmony with the school work performance, with the results that their classroom management skills and teaching skills improved so markedly that students' academic achievement also improved considerably.

This study further revealed that positive and significant relationship existed between induction and work behaviour of newly employed teachers in private secondary schools in Rivers State. This finding is also in accord with Hangul (2017) who reported that induction improved the work behaviour of beginner teachers in the areas of classroom management, lesson plan writing, and time management as well as in handling of instructional materials. This was because the newly employed teachers were given further knowledge that injected zeal and creativity in their work performance.

Grimble (2017) further reported that induction exercise afforded school managers to allay the fears, anxieties and doubts that often assails most novice teachers entering teaching profession, adding that the pep talks given to encourage new teachers during induction programmes boosted their confidence and helped to improve their work behaviours with the result that teachers work behaviour improved so significantly that their productivity was manifest in improved students' achievement. These findings tally with the assertions of Modebelu et al (2016) who stated that induction programme plays important part in integrating beginner teachers into the school community. 
Conversely, this finding contradicted partly, the study of Lopez (2015) who reported that induction exercise organized in schools in Salinas Valley impacted very little on the professional development of beginner teachers. This was because the content of the programmes they were exposed to were what they learnt during the pre-service training and thus added no or little value to their professional development (Rahabav (2016). This highlights the importance of articulating the content of induction exercise towards addressing the identified learning needs of beginner teachers. This resonates the remarks of Mingo (2012) who asserted that the effectiveness of induction exercise is adjudged by the extent such induction exercise is able to help newly employed teacher to acquire new teaching and classroom management abilities, adjust to work performance procedures of the school and administrative responsibilities, as well as the mind-set required to confront certain psychological challenges (such as uneasiness, anxiety) and other relational impediments that newly employed teachers often encounter during probation period.

In his own view, Nghaamwa (2017) added that attrition rate of newly employed teachers is another standard for measuring induction success, adding that newly employed teachers need strong school leadership support to balance probable scepticism and worries that often beset newly employed teachers. These findings also corroborate the reports of Kukuru (2018) whose findings positively associated induction/orientation programme with better work behaviours on the part of trainee teachers in Ondo State Nigeria. The scholar further attributed the positive and strong relationship that existed between induction and newly employed teachers to work behaviour to the quality of planning and purposeful implementation that oversaw the induction exercise. This implies that schools organizing induction should ensure that they first of all identify the learning needs of the new teachers, articulate and sequence relevant activities that will help to prepare newly employed teacher on how to perform their new roles, deals with the emerging challenges and advance their career in teaching profession.

\subsection{Supervision and Work Behaviour of Newly Employed Teachers in Private Secondary Schools}

As noted in previous paragraph, this study found out that positive but weak relationship existed between supervision and work behaviour of newly employed teachers in private secondary schools in Rivers State. This is because supervision helped newly employed teachers to acclimatize with the school lesson note writing patterns and school routine, with the result that newly employed teachers gained new knowledge and mastery of classroom management skills. This finding is in line with Rahabav (2016) whose study investigated the effectiveness of instruction supervision in some Indonesian schools and found out that supervision was so haphazardly planned and coordinated that even the supervisors were so incompetent that trainee teachers lost interest and commitment to the exercise, resulting in failure of the programme altogether. No wonder Abraham (2013) and Kaegon (2012) highlighted the importance of intelligent and quality supervisors who have the required mental capacities to observe, evaluate and educate new teachers and guide them aright towards becoming better teachers. Kaegon (2012) added that supervisors should be knowledgeable and experienced individuals with adequate repertoire of knowledge in pedagogy in order to function effectively in supervisory capacity. In like manner, this study also validated the hypothesis that says there was no significant relationship between supervision and work behaviour of newly employed teachers in private secondary schools in Rivers State.

This finding is consistent with Sule et al. (2015), whose study on influence of principals' supervisory strategies on teacher job performance revealed insignificant relationship between supervisors' approach to supervision and teacher performance in terms of instructional skills, classroom management and disciplinary techniques, evaluation approaches and relational skills. Supervision is an important aspect of educational administration that requires adequate budgetary allocation for the training of would be supervisors, even mentors too. This is important because an earlier study conducted by Okoroma (2005) to ascertain the connection between supervision and teacher productivity in public schools in Rivers State showed that inadequate professional competencies on the part of the supervisors combined with poor funding to weaken the effectiveness of supervision in the state schools. 
On the contrary, a study carried out by Alimi and Akifolarin (2012) in Ondo State to determine the impact of certain supervisory approaches showed that inspection, punctuality checks, marking scheme of work, classroom visitation and observation on the part of the supervisors reportedly improved work behaviour of teacher that students' academic achievement increased correspondingly. The findings of present study further contradicts the findings of Okobia (2015) and that of Eya and Leanard (2012) who in their respective studies reported that supervision is exceedingly capable of accelerating changes in work behaviour of teacher in the direction that enhances desirable abilities that epitomize a professional teacher. The implications of these findings suggest that lack of purposeful supervision is a negative function of poor work behaviour on the part of novice teachers, which by extension may lead to poor academic performance of students. It is therefore of no surprise that Sule et al (2015) associated inadequate supervision of novice teachers to instructional practices that fell short of professional standard, and may have answers to observable low quality in instructional delivery among teachers in many private secondary schools in the state as suggested by these findings.

\section{CONCLUSION}

This study has provided evidence that induction is an important principal assimilation process that have strong and positive relationship with work behaviours of newly employed teachers. Based on this, this study concludes that induction significantly improved the work behaviour of newly employed teachers in private secondary teachers in Rivers State.

\section{RECOMMENDATIONS}

In line with the findings the following recommendations were made:

- School managers should re-evaluate the modalities used in supervising newly employed teachers with a view to improving its processes to foster assimilation of newly employed teachers.

- In planning supervision exercise, administrators should assess the strengths and weaknesses of newly employed teachers in order to determine the areas they need supervisory supports to improve on their performance abilities in classroom.

\section{REFERENCES}

[1] Abraham, N. M. (2013). Educational administration in Nigeria. Port Harcourt: Pam Unique Publishing Coy. Ltd.

[2] Alimi, O. S. \& Akinfolarin, C. A. (2012). The impact of selected modes of instructional supervision activities on students' academic performance in senior secondary schools in Ondo State, Nigeria. Education Research Journal, 2(1), 1-6.

[3] Cook, J. (2009). Coming into my own as a teacher: Identity, disequilibrium, and the first year of teaching. New Educator, 5(4), 274-292.

[4] Dishena, R.N. 2014. Beginner teachers' perceptions of school-based induction programmes at selected primary schools in Windhoek - Namibia. Unpublished M.Ed. thesis. Pretoria: University of South Africa.

[5] Eya, P.E. \& Leonard, C.C. (2012). Effective supervision of instruction in Nigerian secondary schools: Issues in quality assurance. Journal of Qualitative Education, 8(1), 1-12.

[6] Grimble, K. L. (2017). New Teacher Mentees' Perceptions of Mentorship as an Assimilation Strategy. Unpublished Doctoral Dissertations: Walden University. Retrieved from http://www.edweek.org/media/ eperc_assimilation .pdf

[7] Hendrik, S.W. (2016). The impact of teacher mentoring on student achievement in disadvantaged schools. Unpublished Master's Degree Submitted to the Department School of Education Studies in the Faculty of Education at the University of the Free State. Retrieved from http://www.edweek.org/media/eperc_impact of teacher mentoring_1221.pdf

[8] Hangül, S. (2017). An Evaluation of the New Teacher Induction Program in Turkey through the Eyes of Beginning Teachers. Journal of Education and Practice, 8(10), 191-201.

[9] Kaegon, L. E. S. (2012). Qualities of a good supervision. In J.D. Asodike, L.E.S. Kaegon, O.E. Olawolu $\&$ N. Amadike. Educational Planning and Supervision: An introductory text. Port Harcourt: Infomedia Grafik.

[10] Ikegusi, N. G. \& Modebelu, M. N. (2016). Towards Training and Development Needs in Education. Educational Management. In Modebelu, M. N., Eya, O. L., Obunadike, J.The Nigeria Perspective. Awka: SOCOA Heritage Nigeria Ltd. 
[11] Kessels, C. (2010). The influence of induction programs on beginning teachers' well-being and professional development. Netherlands Organization for Scientific Research (NWO). Project no. 411-02203.

[12] Kukuru, J.D. (2018). Effectiveness Degree on Orientation for Beginning/Newly Transferred Teachers in Ondo State Nigeria. International Journal of Technology and Inclusive Education, 7(2), 1260- 1268

[13] Lunenburg, F, C. (2011). Orientation and induction of the beginning teachers. National Forum of Educational Administration and Supervision Journal, 28(4): 1-5

[14] Mingo, A. L. W. (2012). Evaluating the Impact of the Beginning Teacher Induction Program on the Retention Rate of Beginning Teachers. Unpublished Doctoral Dissertations of Gardner-Webb University. Retrieved from ResearchOnline@ ND at http://researchonline.nd.edu.au/edu_reef/334

[15] Mlindazwe, T. (2010). Guidelines for The Development of an induction Programme for the Education Management Development Centre, Metropole: South District. Unpublished MPA thesis. Cape Town. University of Stellenbosch. Retrieved from https://files.eric.ed.gov/fulltext/PP951939.pdf

[16] Modebelu, M.N. (2008). Supervisory behaviour and teacher satisfaction in secondary schools. Nigerian Journal of Educational Management, 7(1), 1-12

[17] Nghaamwa, T. N. T. (2017). An analysis of the influence of induction programmes on beginner teachers' professional development in the Erongo Region of Namibia. Thesis presented in partial fulfilment of the requirements for the degree Masters in Public Administration in the faculty of Management Science at Stellenbosch University. Retrieved from ResearchOnline@ND at http://researchonline.nd.edu.au/edu_ thesis/29.

[18] Nwadiani, M. (2008). Education in foreign countries: lessons for policy planning and practice, Benin City: Monose, Amalgamates.

[19] Okobia, T.A. (2015). Approaches to supervision of instruction, education and development. Journal of the Nigerian Educational Research Council, 2(1), 292-299.

[20] Okoroma, N. S. (2005). School Supervision and Teacher Effectiveness In Secondary Schools in Rivers State. The Nigerian Journal of Research and Production, 6 (2) 130-139

[21] Rahabav, P. (2016). The Effectiveness of Academic Supervision for Teachers. Journal of Education and Practice, 7(9) 47-55

[22] Sule, M. A., Ameh, E. \& Egbai, M. E. (2015).Instructional Supervisory Practices and Teachers' Role Effectiveness in Public Secondary Schools in Calabar South Local Government Area of Cross River State, Nigeria. Journal of Education and Practice, 6 (23)43-47.

[23] Ukaigwe, P. C. \& Igbozuruike, I. U. (2019). Planning: A Tool for Administration of Teachers' Competence Development Programmes for Improved Service Delivery in Secondary Schools inRivers State, Nigeria. Advances in Social Sciences Research Journal, 6(1) 91-100.

Citation: Dr. Ukaigwe, P. C*, Uchenyi, T. I. “Principals' Assimilation Techniques and Work Behaviour of Newly Employed Teachers in Private Secondary Schools in Rivers State, Nigeria". International Journal of Humanities Social Sciences and Education (IJHSSE), vol. 7, no.1, 2020, pp. 64-73. doi: http://dx.doi.org/10. 20431/2349-0381.0701007.

Copyright: (C) 2020 Authors. This is an open-access article distributed under the terms of the Creative Commons Attribution License, which permits unrestricted use, distribution, and reproduction in any medium, provided the original author and source are credited. 